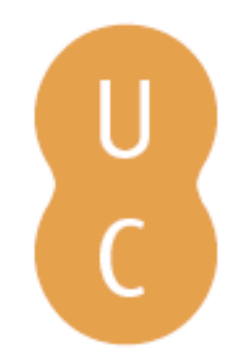

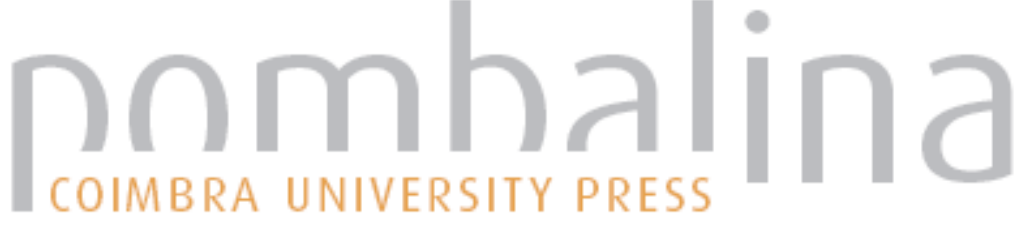

\section{Ignition of wood subjected to the dynamic radiant energy flux}

\author{
Autor(es): $\quad$ Filkov, Alexander; Kuznetsov, V.T.; V.O, Guk
}

Publicado por: Imprensa da Universidade de Coimbra

URL

persistente: $\quad$ URI:http://hdl.handle.net/10316.2/34462

DOI: $\quad$ DOI:http://dx.doi.org/10.14195/978-989-26-0884-6_89

Accessed : $\quad$ 26-Apr-2023 09:55:47

A navegação consulta e descarregamento dos títulos inseridos nas Bibliotecas Digitais UC Digitalis, UC Pombalina e UC Impactum, pressupõem a aceitação plena e sem reservas dos Termos e Condições de Uso destas Bibliotecas Digitais, disponíveis em https://digitalis.uc.pt/pt-pt/termos.

Conforme exposto nos referidos Termos e Condições de Uso, o descarregamento de títulos de acesso restrito requer uma licença válida de autorização devendo o utilizador aceder ao(s) documento(s) a partir de um endereço de IP da instituição detentora da supramencionada licença.

Ao utilizador é apenas permitido o descarregamento para uso pessoal, pelo que o emprego do(s) título(s) descarregado(s) para outro fim, designadamente comercial, carece de autorização do respetivo autor ou editor da obra.

Na medida em que todas as obras da UC Digitalis se encontram protegidas pelo Código do Direito de Autor e Direitos Conexos e demais legislação aplicável, toda a cópia, parcial ou total, deste documento, nos casos em que é legalmente admitida, deverá conter ou fazer-se acompanhar por este aviso. 


\section{ADVANCES IN}

Forest Fire

\section{RESEARCH}

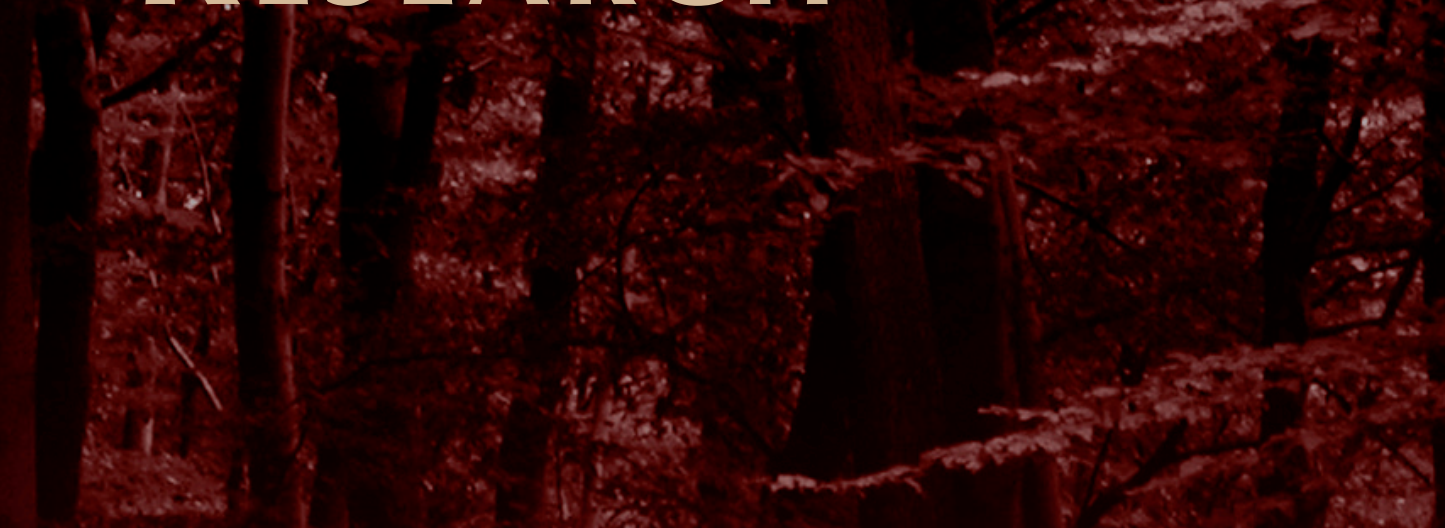

\section{DOMINGOS XAVIER VIEGAS}

\section{EDITOR}




\title{
Ignition of wood subjected to the dynamic radiant energy flux
}

\author{
Alexander Filkov, Kuznetsov V.T., Guk V.O \\ National Research Tomsk State University, 36 Lenin Ave., Tomsk, Russia, aifilkov@gmail.com
}

\begin{abstract}
In this paper we analyzed the ignition of the wood samples subjected to the dynamic heat flux. The experimental setup was created on the base of the optical wave "Uran-1" with a radiation source. The intensity of the heat flux was changed during the experiment by moving the test sample along the optical axis of the elliptic reflector in the setup. Pine wood was used as the test samples. We received the delay times for ignition of pine wood during heating under conditions of the decreasing and increasing heat flux. The received data were compared with the data for a static heat flux.
\end{abstract}

Keywords: wood, dynamic radiant energy flux, wood, ignition time

\section{Introduction}

In [1] it is reported that the ignition process is essentially dependent on the type of heat flux, whether it is static or dynamic (when the ignition of fuels is initiated by time-dependent heat flux). At the same time, the ignition of fuels under dynamic conditions has been insufficiently studied. There are only some experimental work [2,3], where the ignition of fuels was carried out under dynamic conditions of heat supply. Taking into consideration that the dynamic type of the heat flux dominates in the real conditions, the urgency of this problem is obvious.

\section{Methods}

In [1] the first results were received, in particular, it was developed an experimental technique. The radiant energy source was an Uran-1 optical wave with a DKsR-10000 (Figure 1).
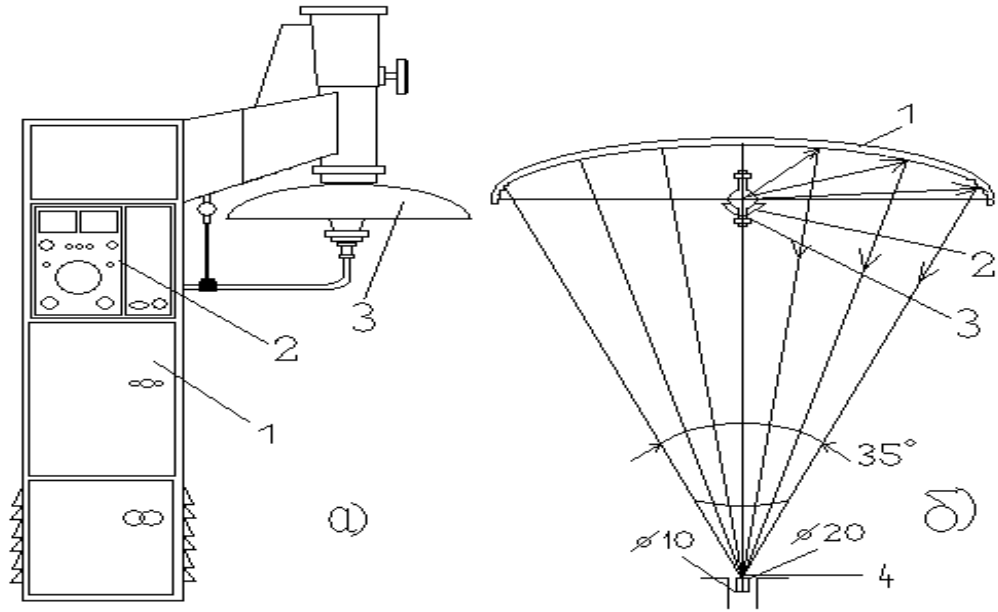

Figure 1. The scheme of experimental installation: a) optical furnace URAN-1: 1- power supply, 2 - control panel, 3 radiator; b) optical radiator: 1 - reflector; 2 -counter reflector; 3 - lamp; 4 -action spot

Of the $10-\mathrm{kW}$ power generated by the lamp, optical radiation accounted for only $5.5 \mathrm{~kW}$. The radiation spectrum distribution was as follows: $0.5 \mathrm{~kW}(9 \%)$ was in the ultraviolet region, $2 \mathrm{~kW}(36 \%)$ in the visible region, and $3 \mathrm{~kW}(55 \%)$ in the infrared region. The setup provided not less than $95 \%$ stability of the radiation in time and not less than $87 \%$ uniformity of the radiant energy flux distribution in a 
spot of diameter $2 \cdot 10^{-2} \mathrm{~m}$. With a deviation of $2 \cdot 10^{-3} \mathrm{~m}$ from the focal plane along the optical axis, the change in the radiant flux density did not exceed $5 \%$. The diameter of the focused flux was about $2 \cdot 10^{-}$ ${ }^{2} \mathrm{~m}$.

The recording unit provided measurements of the radiant flux density, exposure time, the onset of flame and controlled experimental conditions. It included a radiant flux density sensor, diodes, relays and N-117 light-beam oscillograph.

The density of a radiant energy flux in a focal spot was controlled by using radiation attenuators and a smooth change of electric power applied to the xenon lamp. The attenuators of the radiant energy flux were a metal grid that was placed perpendicularly to the optical axis at a distance of 0.3-0.4 m from the focal plane. The system of gates protects the test sample against heating by the radiant flux and dosed supply of energy radiation.

The dynamic flow was modeled by the movement of the sample along the optical axis. For the movement of the sample it was used the following installation (by the example of the decreasing flux of radiant energy, Figure 2).

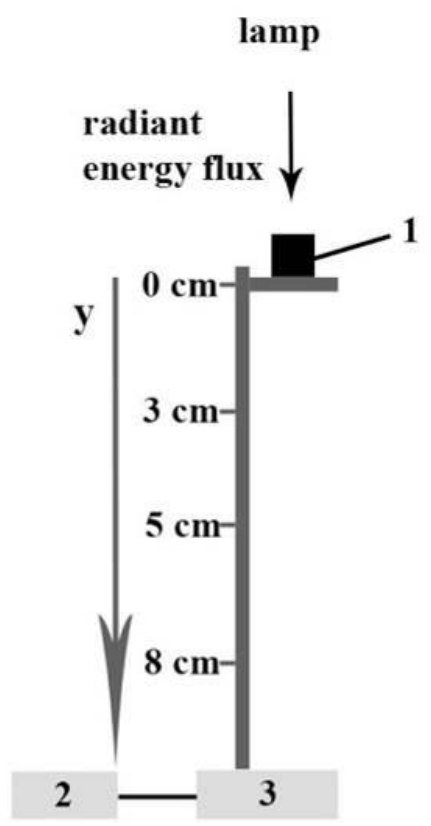

Figure 2. Installation for the movement of the sample: 1 is the sample, 2 is the remote control of motion platform with a sample; 3 is the mechanism that move the sample, $y=0 \mathrm{~cm}$ is the focal plane; $3,5,8 \mathrm{~cm}$ are the distances from the focal plane

Simultaneously with the opening of the gate, the transporter was turn on and the sample started moving with a constant speed of $0.117 \mathrm{~m} / \mathrm{s}$. The opening (closing) time of the gate was $410^{-2} \cdot \mathrm{sec}$.

The test procedure was as follows. The intensity of the radiant flux was measured by a calorimeter fixed to the holder at the upper and lower points of the optical axis. Then the test sample was located on the place of the calorimeter and tested. The registration unit recorded the opening time of the gate and the appearance of flame. Ignition of the condensed substance was determined by the appearance of flame on the sample surface.

The calorimeter was a copper disk $10^{-2} \mathrm{~m}$ in diameter and $3 \cdot 10^{-3} \mathrm{~m}$ thick with a thermocouple calked in the center of the disk to a depth of $1.7 \cdot 10^{-3} \mathrm{~m}$. The thermocouple was obtained by contact welding of copper and constantan wires with a diameter of 100 microns. The receiving surface of the calorimeter was coated with lampblack. In the radiation spectrum of $0.36-1.1 \mu \mathrm{m}$, the reflection coefficient of the 
blackened surface of the calorimeter was $1.5-2.0 \%$. The measurement error of the radiation intensity did not exceed $10 \%$. The heat flux density was measured in the range $q=20-110 \mathrm{~W} / \mathrm{cm}^{2}$.

To determine the density of radiant flux, we experimentally measured the heating rate of the copper disc subjected to radiation coming to the blackened surface. The radiant flux density was calculated by the formula:

$$
q=\frac{m c}{(1-b) S} \cdot \frac{\Delta T}{\Delta t}
$$

where $m$ is the mass of the disk; $c$ is the specific heat; $S$ is the area of the blackened surface of the disc; $b$ is the reflection coefficient; $\frac{\Delta T}{\Delta t}$ is the rate of heating.

The delay time of ignition was determined by a photoelectric method. The ignition time was taken as the time interval from the beginning of exposure to the radiant energy flux to the occurrence of flame over the surface of the sample. Radiation of flame was registered using photodiodes. The H-117/1 oscilloscope was used for recording electrical signals. In measurements of the ignition time from the occurrence of flame, the error is not more than $4 \%$ and is determined mainly by the physicochemical properties of the material studied.

Pine wood (Pinus Silvestris) was used as the test samples (Figure 3). The samples were cylinders $1.9 \cdot 10^{-2} \mathrm{~m}$ in diameter and $1.5 \cdot 10^{-2} \mathrm{~m}$ in height. The surface of the samples, absorbing radiation, was covered by lampblack.

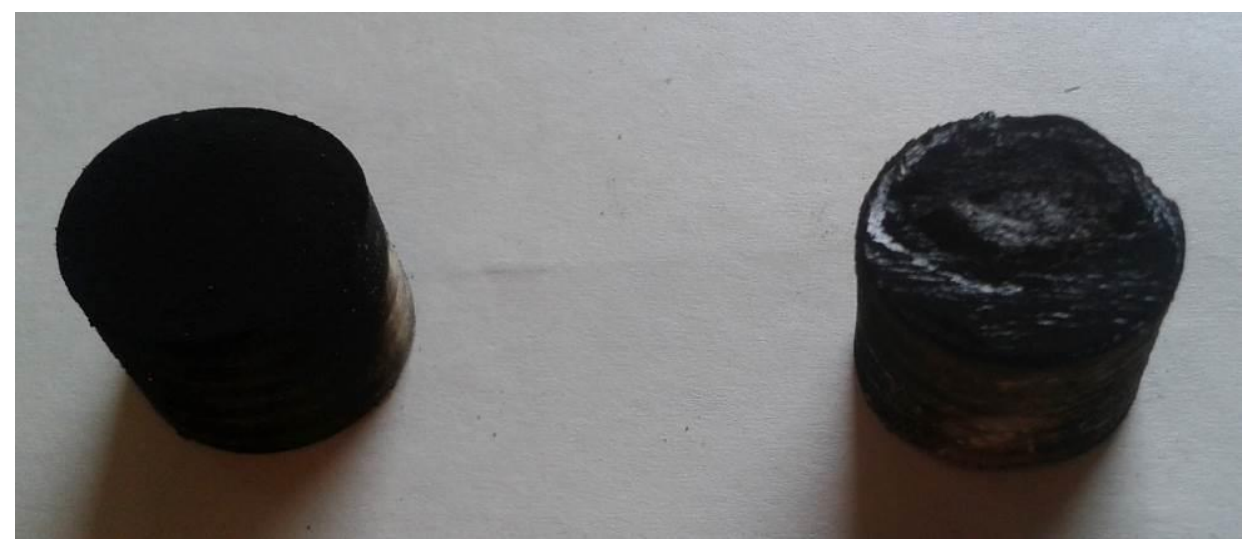

Figure 3. Wood sample before (left) and after experiment (right)

The light radiation was incident on the sample perpendicularly to the wood fibers. The investigations were carried out in air at atmospheric pressure. The initial temperature of the samples corresponded to room temperature $-297 \mathrm{~K}$. The moisture content of the samples was $\mathrm{W} \approx 1.8 \%$. The absolutely dry state of wood was achieved by predrying in a drying box at $376 \mathrm{~K}$ for 48 hours. Unchangeable moisture content of the samples was provided by a desiccator filled with silica gel. The moisture content of the samples was determined with an accuracy of 0.01\% using a A\&D MX-50 moisture content analyzer.

\section{Results and discussion}

To compare the delay time of ignition under static and dynamic conditions, the heat flux was averaged under dynamic conditions. For this purpose, the following method was used. The intensity of the radiant energy flux was measured with a microcalorimeter at fixed distances from the focal plane of the reflector. Knowing the velocity of the sample along the optical axis of the elliptical reflector we 
can turn from fixed values of the distance to the time. In this case, the dependence of the heat flux on time is well enough (correlation $\mathrm{R}^{2}=0.997$ ) approximated by the function (Figure 4):

$$
q=a e^{ \pm 0.7 t}-2
$$

where $q$ is the heat flux, W/ $\mathrm{cm}^{2}$; $t$ is the time, s; $a$ is the nondimensional coefficient, "+" - increasing heat flux; "-" - decreasing heat flux.

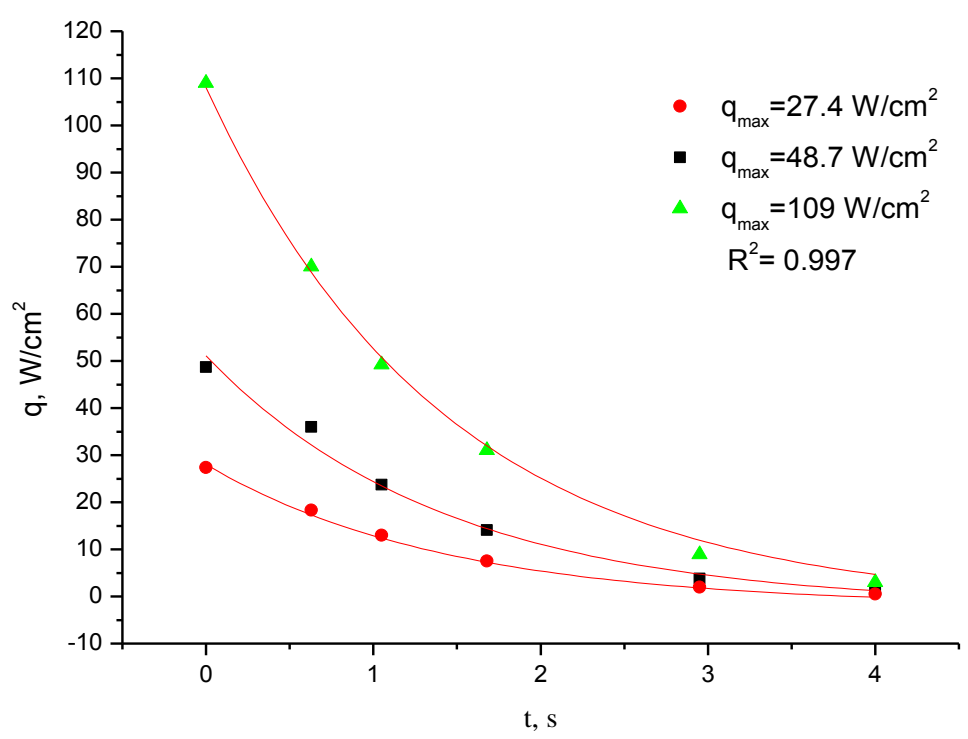

Figure 4. Heat flux versus time when the sample is moved from the focal plane

Thus, depending on the value of heat flux in the focal plane ( $\mathrm{t}=0)$ we can determine a coefficient $a$ and dynamic changes of the heat flux at the surface of the moving sample. The delay time of ignition was measured using a photodiode. Knowing the ignition delay time of the sample we can find a heat flux in the ignition point using a distribution curve $\mathrm{q}(\mathrm{t})$. Since the sample of pine ignites within one second in the tested range of the heat flux, then from Figure 4 it can be seen that the curve is quasilinear in this range. In this connection, the average heat flux was determined as the arithmetic mean value for dynamic conditions.

Figure 5 shows the ignition delay times of the pine samples under decreasing $(q=f(t))$ and static ( $\mathrm{q}=$ const) heat flux. 


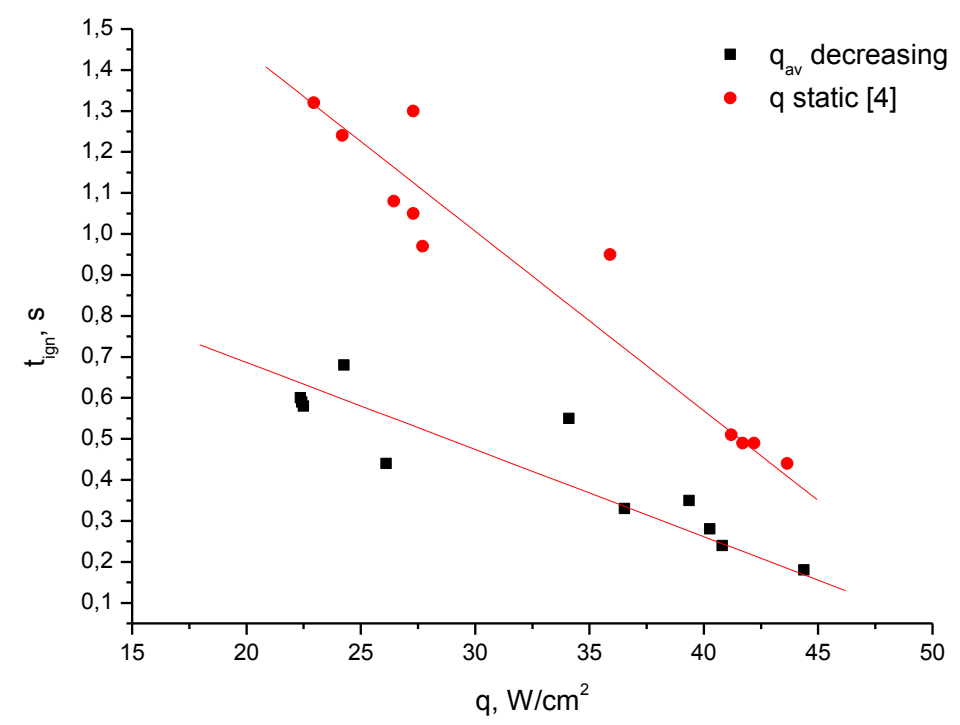

Figure 5. Ignition delay times of the pine samples versus heat flux for dynamic (decreasing heat flux) and static conditions

When the radiation flux decreases, the delay time for ignition of the pine samples is 2-2.5 times less than that for the constant radiation flux. At the same time, Figure 5 shows that the decrease in value of heat flux leads to the fact that the delay time of ignition increases faster under static conditions than under dynamic ones. These results do not contradict the paper [3], where it was experimentally shown that in the case when the heat flux increases, the delay time for ignition of nitrocellulose is greater than that for the constant heat flux.

In a similar way, according to the formula (2) the flux of radiant energy was determined at the moment of ignition for increasing flux. The average heat flux was determined using the method for determination of the average value for interval dynamic rows [5]. Figure 6 shows the delay time to ignite the pine samples for the increasing $(\mathrm{q}=\mathrm{f}(\mathrm{t}))$ and static $(\mathrm{q}=\mathrm{const})$ radiant energy flux.

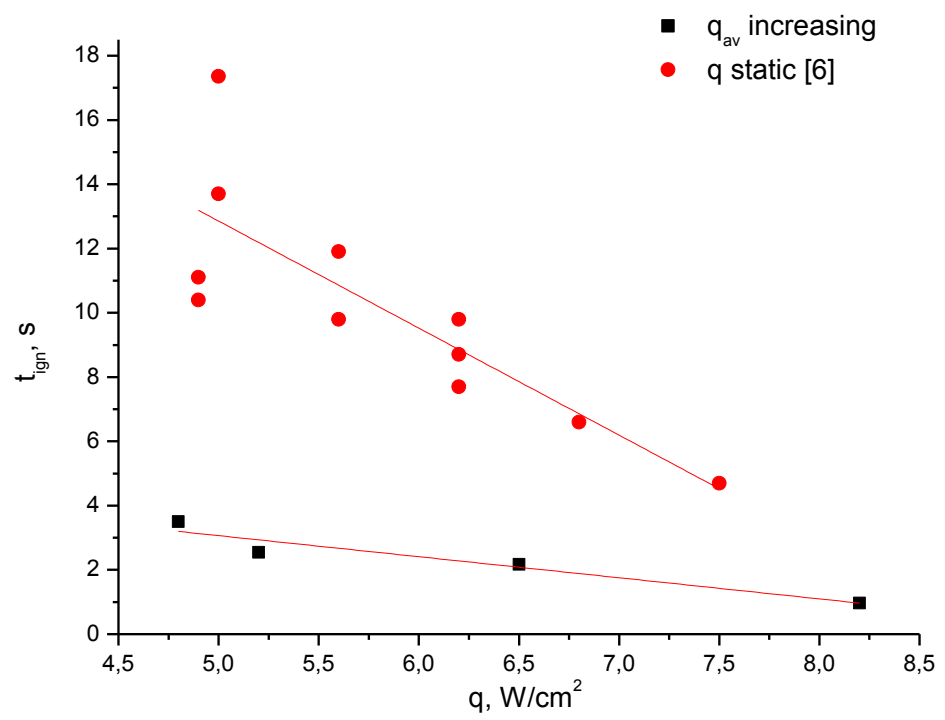

Figure 6. Ignition delay times of the pine samples versus heat flux for dynamic (increasing heat flux) and static conditions 
The analysis of the curves in Figure 6 shows that the ignition delay time for the increasing flux of radiant energy is smaller than for a constant flux. The difference in time is from 2 to 3 times. For the decreasing flux (Figure 5), a similar pattern is observed. However, the ignition delay time for the increasing flux of radiant energy decreases slower than for the decreasing flux with the increase in time. The data obtained are in qualitative agreement with the results of mathematical modeling of dynamic conditions for heating of wood in [7].

At a result we have received the delay times for ignition of pine wood during heating under conditions of the decreasing and increasing heat flux. The received data were compared with the data for a static heat flux $[4,6]$.

The results obtained can be used to improve the prediction of dangerous zones for ignition of wood in wildland and anthropogenic fires.

\section{Acknowledgements}

This work was supported by the Tomsk State University Competitiveness Improvement Program, the Government Assignment in the Field of Scientific Activity (number 1624), the Russian Foundation for Basic Research (project number 14-01-00211-a and 14-33-50115-mol-nr) and a Scholarship from the President of the Russian Federation (number SP-3968.2013.1).

\section{References}

1. Filkov A.I., Kuznetsov V.T., Guk V.O., Telyakov E.Sh., Enalejev R.Sh. Ignition of Wood Under Dynamic Conditions of Supply of Radiant Energy Flow // Proceedings of the 4th Fire Behavior and Fuels Conference (Saint-Petersburg, Russia, July 1-4, 2013). - USA, IAWF. 2013. Pp. 57.

2. Rosenband R.Sh., Barzykin V.V., Merzhanov A.G. Ignition of Condensed Substances by the Convective Flux of Average Intensity under Dynamic Conditions. Combustion, Explosion and Shock Waves, 1968. V.4. No. 2. Pp. 171-175. (in Russian)

3. Enaleev R.Sh., Mateosov V.A., Sinaev K.N., Dinavetsky V.D., Gainutdinov R.Sh. Experimental Research into Ignition of Condensed Substances under Dynamic Conditions for Supply of Radiant Energy. In the book: Physics of Combustion and Methods of Research, Cheboksary: Chuvash Univ. 1973. Pp. 80-86. (in Russian)

4. Kuznetsov V.T., Fil'kov A.I. Ignition of Various Wood Species by Radiant Energy // Combustion, Explosion, and Shock Waves. 2011, Vol. 47, No. 1. Pp. 65-69.

5. Baliiova V.S. Statistics of Questions and Answers. Textbook. M.: T.K. Welby, 2004. 344 p. (in Russian)

6. Boonmee N., Quintiere J. G. Glowing and flaming autoignition of wood // Proceedings of the Combustion Institute. Vol. 29. 2002. Pp. 289-296.

7. Enaleev R.Sh., Krasin I.V., Gasilov V.S., Chistov Yu.S., Tuchkova O.A. Ignition of Wood // Herald of Kazan Technological University, 2013. V. 16. No. 10. Pp. 99-106. 